\title{
Application of Membrane Separation Technology for Developing Novel Dairy Food Ingredients
}

\section{Chenchaiah Marella ${ }^{1 *}$, K. Muthukumarappan² and L. E. Metzger ${ }^{3}$}

${ }^{1}$ Assistant Professor and Leprino Chair in Dairy Products Technology, Dairy Science Department, California Polytechnic University, San Luis Obispo, CA 93407, USA ${ }^{2}$ Distinguished Professor and Graduate Program coordinator, Agricultural and Biosystems Engineering Department, South Dakota State University, Brookings, SD 57007, USA

${ }^{3}$ Professor and Alfred Chair in Dairy Education, Dairy Science Department, South Dakota State University, Brookings, SD 57007, USA

\begin{abstract}
In several processing industries, separation of different components from a mixture is an important unit operation. Sometimes the separated component is an important product, and in some instances it is a waste product. There is a variety of technologies available for use in separations, each operating based on physical and chemical properties of the mixture. One of the fundamental separation processes that brought about a major change in processing of dairy co-product streams is membrane separation technology. Membrane separations work on the basis of differences in size and shape of the molecules. Today dairy industry accounts for major share in the total membrane area installed in food processing, accounting for about 300,000 square meters of membrane area installed worldwide. Reverse Osmosis (RO), Nanofiltration (NF), Ultrafiltration (UF) and Microfiltration (MF) processes have been in use in the dairy industry for about 4-5 decades. Each of these processes is used for specific application. The phenomenal growth in the application of membrane separation technology in the dairy processing brought into focus the need for novel membranes and processes that enable production of new dairy based ingredients. Now-a-days wide pore UF process is used to develop a-Lactalbumin enriched protein products, loose NF process is used to recover and purify Oligosaccharides, high pressure UF process is used to replace the conventional NF process used for concentrating dairy product streams. In the present paper, new developments in the application of membrane separation in the dairy industry are presented along with the experimental data from the research conducted by the authors.
\end{abstract}

Keywords: Wide pore ultrafiltration; Milk minerals; Spiral wound; Membrane separation; Milk protein concentrate

\section{Introduction}

In several processing industries, separation technology is widely used to separate and in some cases to purify a particular component from the rest of the mixture. The target component might be the desired product or an unwanted component, separated to increase the purity of the original mixture. Separations take advantage of differences in physical or chemical properties of the mixture of components [1-3]. Of the several separation technologies available, membrane separation technology brought a significant change in dairy food processing. There are several advantages of membrane separation technology when compared to other processes. These include, separation of components at a lower temperature, separating the component in its native state, less energy use etc.

Reverse Osmosis (RO), Nanofiltration (NF), Ultrafiltration (UF) and Microfiltration (MF) are four commonly used membrane separation process in the dairy food processing. These processes have evolved from consistent research and development in the area of new membrane material development as well as applications [4]. Membrane separations have been extensively used in dairy process industry and are used for selective separation of different species. Commonly used separation processes are Microfiltration, Ultrafiltration, Nanofiltration and Reverse osmosis. These processes differ in membrane characteristics, their pore size and operating pressures to which they are exposed to. Reverse osmosis is mainly used to concentrate all the solutes present in a mixture, while removing water in the process. Nanofiltrationis used to concentrate the solutes while partially allowing the passage of some lactose and monovalent salts, thereby minimizing the effect of osmotic pressure. Conventional ultrafiltration is used to remove lactose and soluble salts from dairy mixtures. Microfiltrationis widely used to remove bacteria, somatic cells, fat and lately micellar casein from skim milk [5].

\section{Applications in Dairy Industry}

Milk is an essential constituent of many foods. It is a complex mixture of different components like fat, protein, lactose, minerals, etc. These components have specific nutritional and functional properties. Fractionation of these components will enable pure ingredients to be produced that have the advantage of constant quality [4,6]. Accordingly membrane processing is implemented in the dairy industry on a wide scale. The dairy industry accounts for the lion's share of the total membrane area installed in the food industries. It is estimated that about $500,000 \mathrm{~m} 2$ of membrane area is installed in dairy applications worldwide, and more than $70 \%$ of this area is in whey processing [7] especially in preparation of whey protein products. Specific applications of membrane processing in the dairy industry include fractionation of milk fat from whole milk, removal of bacteria and spores from skim milk, production of milk protein and native casein concentrates recovery and fractionation of whey proteins etc. Various applications

*Corresponding author: Chenchaiah Marella, Assistant Professor and Leprino Chair in Dairy Products Technology, Dairy Science Department, California Polytechnic University, San Luis Obispo, CA 93407, USA, Tel: 605690 2186; E-mail: Marella@calpoly.edu

Received July 31, 2013; Accepted September 28, 2013; Published October 08 , 2013

Citation: Marella C, K Muthukumarappan, L E Metzger (2013) Application of Membrane Separation Technology for Developing Novel Dairy Food Ingredients. J Food Process Technol 4: 269. doi:10.4172/2157-7110.1000269

Copyright: $\odot 2013$ Marella C, et al. This is an open-access article distributed unde the terms of the Creative Commons Attribution License, which permits unrestricted use, distribution, and reproduction in any medium, provided the original author and source are credited. 
of membrane separations in the dairy processing have been extensively reviewed [8-10].

\section{Novel Membrane Processes and Applications}

\section{Pervaporation}

In the pervaporation process, feed liquid flows on one side of the membrane, and the permeateis removed as vapor from the other side of the membrane. Pervaporation is the only membrane process where a phase transition occurs with the feed being liquid and permeate being vapor. This is made possible by maintaining partial vacuum on the permeate side of the membrane. The components to be separated from the mixture need to be absorbed by the membrane, should diffuse through it and is expected to easily go into the gaseous phase on the other side of the membrane [11]. The required vapor pressure difference across the membrane can be maintained by a vacuum pump or by condensing the vapor produced which spontaneously creates a partial vacuum.

Pervaporation process can be effectively used for removal of water from liquid organics, water purification and organic/organic separations. Novel application of pervaporation is in purification/ separation of ethanol from fermentation broths. As ethanol forms azeotrope with water at $95 \%$ concentration, pervaporation process appears promising because simple distillation will not work under these conditions. Pervaporation process is successfully used in production of pure water. A variety of membranes has been tried in these applications [5].

\section{Electrodialysis (ED)}

Electrodialysis is a membrane based demineralization process and uses ion exchange membranes. It is widely used in demineralization of liquid foods such as milk and whey and is used extensively in desalination of sea water. ED is known since 1890 but the first successful installation of ED plant was in 1952. The principle of ED process is based on the fact that when an aqueous solution containing ions of different mobilitiesis subjected to an electric field, the ionic species migrate to the respective opposite polarities of the field [11]. The ionic mobility is directly proportional to the specific electrical conductivity of the solution and is inversely proportional to the ionic concentration.

In an ED system, anionic and cationic membranes are arranged in a plate and frame configuration (just like the classic plate heat exchanger) and are placed alternately. The feed solution is pumped to the cells of the system, and electrical potential is applied. The positively charged ions migrate towards the cathode and negatively charged ions move towards the anode. Cations easily pass through the negatively charged cationic exchange membranes but are retained by positively charged anionic exchange membranes. Similarly, anions pass through anion exchange membranes but are retained by the cation exchange membranes. The net result is that one cell (pair of anionic and cationic membrane) becomes enriched / concentrated in ionic species while the adjacent cell becomes depleted of ionic species. The presence of impurities and precipitated materials, as in the case of biological material causes severe concentration polarization of the membranes. The problem is more severe with anionic membranes which are clogged by large organic anions (such as amino acids), precipitated calcium phosphate and denatured proteins [11]. This anionic membrane specific problem can be partially overcome by using neutral membranes in the place of anionic membranes. The advantages of using neutral membranes are that concentration polarization is reduced, easier cleaning cycles and extended process runs. However, the disadvantage includes low degree of separation because only one set of membranes is selective.

\section{Membrane distillation}

Membrane distillation is an evaporation process for separating volatile solvent from one side of a non-wetted microporous membrane. The evaporated solvent is condensed or moved on the permeate side of the membrane. When a hot solution and a cold aqueous solution are separated by a non-wetting membrane, water vapor will diffuse from the hot solution/membrane interface to the cold solution/membrane interface and condense there. So long as the membrane pores are not wetted by both solutions, the pressures on both sides can be different. The microporous membrane in this case acts as liquid phase barrier as water evaporation continues. This arrangement is called the direct contact membrane distillation. The main advantages associated with membrane distillation are: no possibility of entrainment, possibilities of horizontal configurations, low temperature energy sources can be used, reduced the problem of fouling due to the use of hydrophobic membranes, possibility of highly compact designs such as hollow fiber configuration [5].

\section{Separations using liquid membranes}

In separation processes using liquid membranes, the solutes diffuse through liquid contained in a porous support. These separations can be either gas or liquid separations. The solute molecules undergo dissolution in the membrane at the feed/ membrane interface. The dissolved solutes diffuse through the membrane and are desorbed at the other membrane surface. Applications using liquid membranes include waste water treatment: removal of phenol [12], removal of thiomersol from vaccine production effluents [13], trace metal treatment from natural waters. Other applications include removal of citric acid, acetic acid from fermentation broths, separation of gas mixtures, toxic heavy metal ions, separation of sugars etc.

\section{Novel Applications of Membrane Separations in Production of Value Added Dairy Ingredients}

\section{Spiral wound microfiltration in production of Micellular casein concentrate}

In recent years, there has been increased interest in use of microfiltration in production of micellar casein concentrate. Micellar casein concentrate is obtained from microfiltration of skim milk during which most of serum protein and non protein nitrogen components are removed in to permeate thereby increasing the ratio of casein to total protein and casein to true protein. The retentate obtained from this process is a concentrated colloidal suspension containing casein in micellar form, lactose, minerals and some serum proteins. Micellar casein concentrate has potential uses in cheese making, process cheese (as rennet casein replacer), nutritional meal replacements, whipped toppings, coffee whiteners etc [14-16].

To date most of the research on microfiltration of skim milk for production of micellar casein concentrate used ceramic microfiltration membranes. Ceramic membrane systems are capital intensive and membrane replacements are expensive. When compared to these systems, membrane separation systems using polymeric membranes requires less foot print, inexpensive and are familiar with most of the US dairy processors. In recent years, there has been increased interest in assessing the suitability and efficiency of polymeric membranes for production of micellar casein concentrate. It has been shown that using ceramic membranes, more than $95 \%$ of serum protein could be 


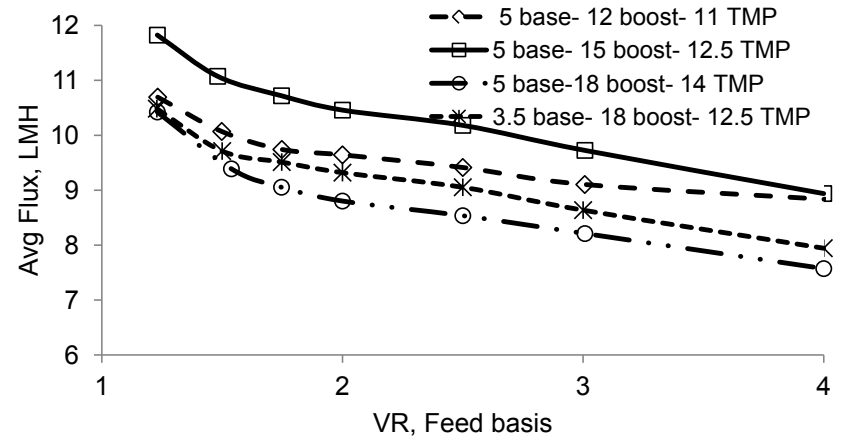

Figure 1: Effect of operating pressure on performance of spiral wound microfiltration process during production of micellular casein concentrate from skim milk. Flux is L per $\mathrm{m} 2 \mathrm{~h}$, TMP is transmembrane pressure and VR is volume reduction. Experiments were conducted at $65 \mathrm{~F}$ temperature using $0.5 \mu$ polyvinyledene membrane.

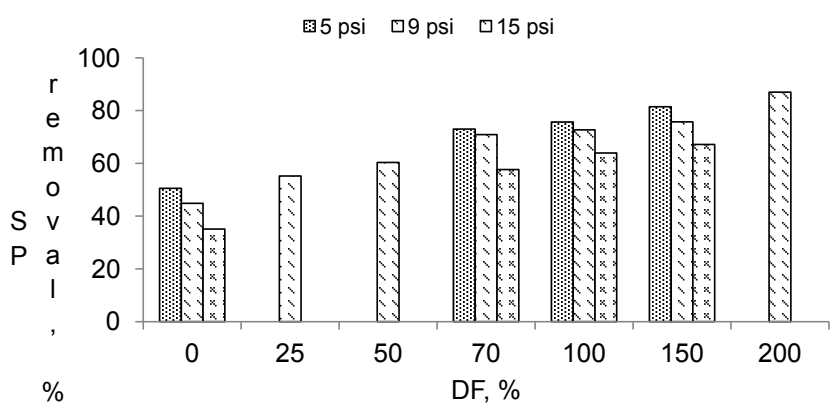

Figure 2: Effect of operating pressure on serum protein removal efficiency during spiral wound microfiltration of skim milk. SP is serum protein, DF is the amount of diafiltration water added during the process.

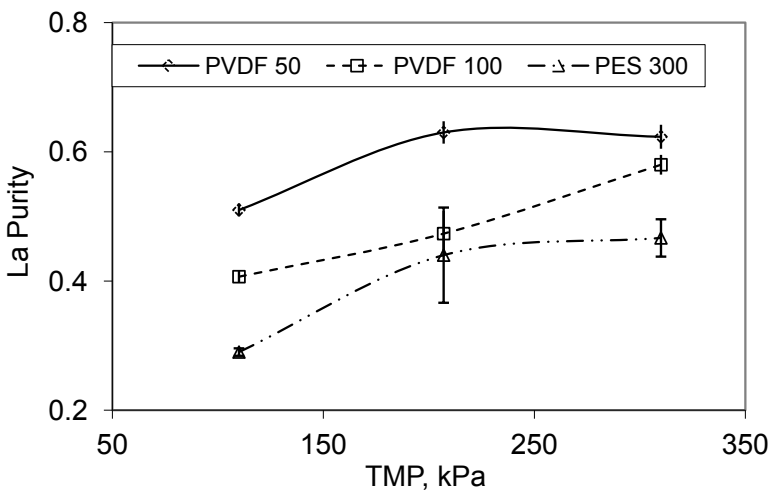

Figure 3: Purity of $\alpha$-Lactalbumin obtained from wide pore ultrafiltration experiments conducted using cheddar cheese whey as feed material. La is aLactalbumin, PVDF 50 and 100 are polyvinyledene fluoride membranes with 50 and $100 \mathrm{kDa}$ molecular weight cut off. PES 300 is Polyehtersulfone membrane with $300 \mathrm{kDa}$ molecular weight cut off. TMP is transmembrane pressure.

removed in a 3 stage process in which diafiltration to a level of $200 \%$ (on feed volume basis) was used. Diafiltration is a process in which water is added to the retentate during microfiltration and further concentration is carried out. This step is intended to improve the serum protein removal and to control the membrane polarization phenomenon. A few studies conducted on the use of polymeric membranes for production of micellar casein concentrate showed that serum protein removal of the order of $40 \%$ was possible without diafiltration and with the use of diafiltration to the extent of $200 \%$ of feed volume, serum protein removal to the extent of $70 \%$ could be achieved [16]. However, these processes were carried out at elevated temperatures with the associated problems with energy consumption, bacterial quality etc. Marella et al. and Metzger et al. [14,17] carried out extensive research with the use of polymeric membranes for production of Micellular casein concentrate from skim milk. In this work, operating parameters such as operation pressure, level of diafiltration etc. were optimized for maximizing the serum protein removal from spiral wound microfiltration process. From this research, it was shown (Figure 1) that operating microfiltration process at a base and differential pressures of 5 and 15 psi resulted in to better flux rates. This research further showed that microfiltration process is extremely sensitive to pressure and operating the process at lower pressure results in maximum serum protein removal (Figure 2).

\section{Wide pore ultrafiltration process for production of value added dairy ingredients}

a-Lactalbumin enriched whey protein concentrate: Traditionally ultrafiltration used in dairy applications utilizes Polyether sulfone membrane with a molecular weight cut off of $10 \mathrm{kD}$. As these membranes have extremely tight pores, the ultrafiltration process using these membranes concentrates all the proteins present in either cheese whey or skim milk that is processed. When cheese whey is processed using the conventional ultrafiltration process, whey protein concentrates and whey protein isolates are obtained. These protein products are mixtures of individual and valuable protein fractions. In order to realize the true value of individual protein fractions, it is essential to fractionate these mixtures into products of individual components. One such high value protein present in cheese whey is a Lactalbumin. Previous research sah used polymeric membranes in hollow fiber configuration $[18,19]$, combination of ceramic and polymeric membranes [20-22] and spiral wound polymeric membranes [23,24]. Using cheese whey as feed material, this research has demonstrated that $\alpha$-Lactalbumin enriched whey protein concentrate can be produced with purity of $62 \%$ can be produce (Figure 3 ). When skim microfiltration permeate (serum whey) is used as feed material, $\alpha$-Lactalbumin purity of as high as more than $80 \%$ can be obtained with proper selection of membranes and operating conditions (Figure 4).

\section{Milk mineral from dairy process streams}

Milk contains a variety of essential minerals and trace elements. The concentration of these minerals ranges from 8 to $9 \mathrm{~g} / \mathrm{l}$. Calcium, Magnesium, Sodium, and Potassium are the main cations present in the milk. Phosphate, Citrate, and Chloride are the main anions. Some of these minerals are present in dispersed form in milk serum while some of these are partially associated with milk components such as proteins (Casein, a-Lactalbumin etc.). This partial association with milk proteins gives structure and stability to milk and milk components. During manufacture of milk products, milk is subjected to various technological treatments such as filtration, acidification etc. These treatments partition the minerals present in the milk between different streams. For example, in cheese making Calcium, zinc, magnesium and phosphorus go with whey and end up in whey powders. Mineral content is higher in acid whey than in sweet whey [25].

Harvesting of milk minerals from dairy byproduct streams not only help overcome the fouling problems but also help the dairy processors to realize the true value of milk minerals. At present, milk minerals are harvested from dairy byproduct streams using some publicly known and some proprietary processes. For example, US Patent 5,639,501 describes 


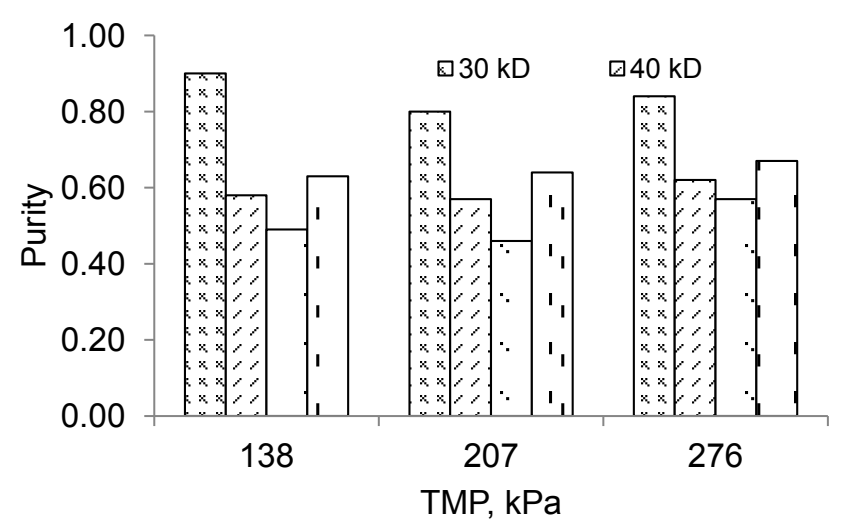

Figure 4: Purity of $\alpha$-Lactalbumin obtained from wide pore ultrafiltration experiments conducted using skim milk microfiltrations permeate as feed material. 30,40 and $100 \mathrm{kD}$ are polyvinyledene fluoride membranes with 30,40 and $00 \mathrm{kDa}$ molecular weight cut off. $300 \mathrm{kD}$ is Polyehtersulfone membrane with $300 \mathrm{kDa}$ molecular weight cut off. TMP is transmembrane pressure. Bars with same letter are not statistically different $(P<0.05)$

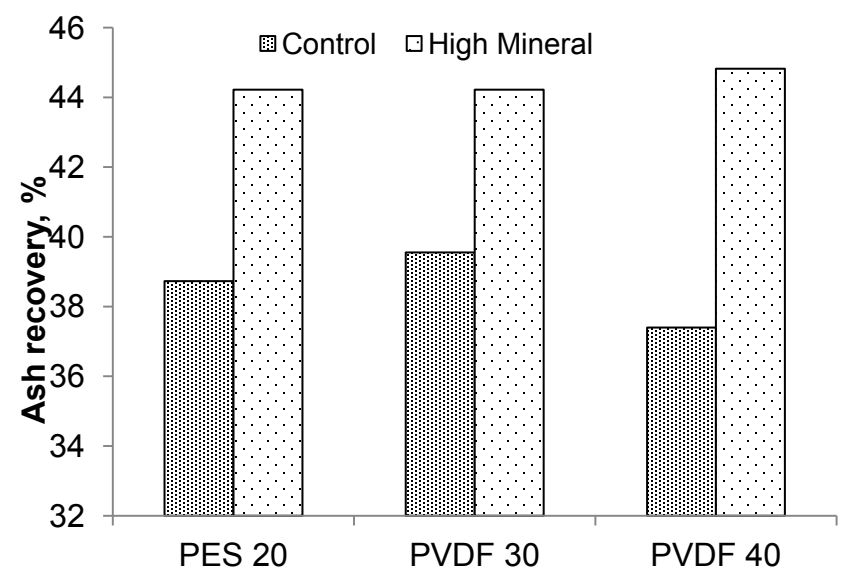

Figure 5: Mineral harvest data from wide pore ultrafiltration experiments. Ultrafiltration permeates obtained from milk protein concentrate manufacturing process were concentrated to $11 \%$ solids in reverse osmosis unit. Control is the feed that has normal level of minerals, High mineral is the feed that has higher mineral content. PES 20 is Polyether sulfone membrane with $20 \mathrm{kDa}$ molecular weight cut off. PVDF 30 and 40 are Polyvinyledene membranes with 30 and 40 kDa molecular weight cut off.

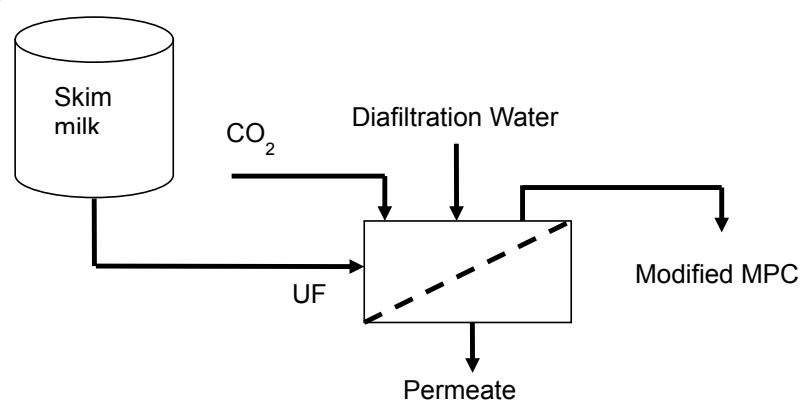

Figure 6: Process for production of milk protein concentrate with a modified mineral content. UF is ultrafiltration and MPC is milk protein concentrate.

a process wherein the $\mathrm{pH}$ of whey permeate stream containing about $15-24 \%$ solids is adjusted to 7.2 using a phosphate compound, heated to
$155 \mathrm{~F}$, and held at this temperature for 20-35 minutes in order to allow calcium phosphate to flocculate and precipitate out. Vyas and Tong [26] developed a process for recovering milk minerals from permeate stream using a combination of $\mathrm{pH}$ adjustment and heat treatment and reported a calcium recovery of $70 \%$. In this research, conventional ultrafiltration membranes with a molecular weight cut off of $10 \mathrm{kDwas}$ used. With the purpose recovering minerals and to develop a wide pore ultrafiltration process that has high permeation rates, Mealy et al. [27] conducted mineral harvest research using wide pore ultrafiltration membranes and reported ash recovery of $44 \%$ (Figure 5). This process using $40 \mathrm{kD}$ PVDF membrane has exceptionally high flux rates of more than $100 \mathrm{LMH}$.

\section{Filtration technology to produce mineral modified milk protein concentrates}

Milk protein concentrate (MPC) is produced by ultrafiltration (UF) of skim milk to produce a product that is partially or completely delactosed and high in protein. During UF, water, lactose, NPN and some soluble salts are removed in to permeate stream. Higher molecular weight constituents such as caseins, whey proteins and some minerals are concentrated into retentate stream. In the production of MPCs, UF membranes with a molecular weight cut off of 5 and 10 $\mathrm{kDare}$ used to concentrate higher molecular weight components such as fat, protein and some salts. UF membranes allow passage of water, lactose, non protein nitrogen and some dissolved salts [28,29]. In some applications, diafiltration step is used in order to wash out more lactose and thereby increase the protein content. Depending on the volume reduction (VR) and extent of diafiltration (DF) applied, a variety of products are produced that range in protein content from 56 to $85 \%$. MPCs with higher protein levels suffer from loss in solubility during storage of the product after production. Several researchers studied the reasons for loss in solubility and mineral mediated aggregation of proteins in one of the primary reasons for loss in solubility of high protein MPCs [30-32]. In-order to improve the solubility of MPCs, Baskhar et al. [33] developed an ion exchange process and showed that depletion of calcium from MPCs prevented loss in solubility of MPCs during storage. Mao et al. [34] used filtration technology where in diafiltration was conducted with the addition of sodium chloride at 50,100 and $150 \mathrm{ppm}$ and showed that this process produced MPC with a modified mineral content. Marella et al. [32] developed a process (Figure 6) for production of mineral modified MPC 80 with injection of carbon dioxide and showed that these MPCs retained its solubility when stored at room as well as elevated temperatures for up to 180 days. The mineral modified MPCs developed from this process showed superior functional properties [35].

\section{Conclusions}

Application of membrane separation technology in the dairy processing industry has brought into sea change in availability of a wide variety of dairy ingredients. Dairy applications account for major share in total membrane surface area installed in food processing industries. As more and more demand for novel dairy ingredients is growing, research is focusing on development of new processing technologies that help production of value added dairy ingredients. Membrane separation technology continues to hold a key role in selective fraction and development of novel dairy ingredients. In this paper, several new applications of membrane separation technology were discussed, and research results were presented. 
Citation: Marella C, K Muthukumarappan, L E Metzger (2013) Application of Membrane Separation Technology for Developing Novel Dairy Food Ingredients. J Food Process Technol 4: 269. doi:10.4172/2157-7110.1000269

\section{References}

1. Mohsenin NN (1980) Physical Properties of Plant and Animal Materials: Structure, Physical Characterstics and Mechanical Properties. Gordan and Breach, New York, NY.

2. Lewis MJ (1990) Physical properties of foods and food processing systems. Ellis Horwood, Chichester, UK.

3. Mulder M (1991) Basic Principles of Membrane Technology. Kluwer academic publishers, Norwell, MA.

4. Marella C (2009) Whey protein fractionation using membrane separation technology. Phd dissertation. South Dakota State University, Brookings.

5. Muthukumarappan K, Marella C (2010) Membrane Processing. In: Mathematica modeling of food processing, Mohammed Farid (Ed), CRC Press, Boca Raton, FL.

6. Huffman LM, Harper WJ (1999) Maximizing the value of milk through separation technologies. J Dairy Sci 82: 2238-2244.

7. Timmer JMK, van der Horst HC (1998) Whey processing and separation technology: state-of-the-art and new developments. In: WHEY 2nd international whey conference, Chicago, 27-29 Oct 1997, IDF, Brussels, pp 40-65.

8. Cheryan M (1998) Ultrafiltration and Microfiltration Handbook, CRC Press, USA.

9. Brans G, Schroen CGPH, van der Sman RGM, Boom RM (2004) Membrane fractionation of milk: state of the art and challenges. J Membrane Sci 243: 263272.

10. Henning DR, Baer RJ, Hassan AN, Dave R (2006) Major advances in concentrated and dry milk products, cheese, and milk fat-based spreads. J Dairy Sci 89: 1179-1188.

11. Kessler HG (2002) Food and bioprocess engineering: dairy technology, Verlag A. Kessler, Germany.

12. Cahn RP, Li NN (1974) Separation of Phenol from Waste Water by the Liquid Membrane Technique. Separation Sci 9: 505-519.

13. Fortunato R, Afonso CAM, Crespo JG, Reis MA (2003) 17th Forum for applied biotechnology: Proceedings. 41

14. Metzger LE, Marella C, Salunke P (2012) Performance of spiral wound microfiltration membranes during production of micellular casein concentrate. Journal of Dairy Science 95: E-Suppl. 2.

15. Nelson BK, Barbano DM (2005) A microfiltration process to maximize removal of serum proteins from skim milk before cheese making. J Dairy Sci 88: 18911900.

16. Zulewska J, Newbold M, Barbano DM (2009) Efficiency of serum protein removal from skim milk with ceramic and polymeric membranes at 50 degrees C. J Dairy Sci 92: 1361-1377.

17. Marella C, Salunke P, Metzger LE (2011) Optimization of spiral wound microfiltration process production of micellar casein concentrate. Journal of Dairy Science 94: E-Suppl. 1.

18. Roger LR, Maubois JL, Guibourg LB, Brule G, Piot M (1984) Process for obtaining an $\hat{I} \pm$ Lactalbumin enriched product from whey and uses thereof. US Patent No. 4,485,040.
19. Bottomley RC (1991) Process for obtaining concentrates having a high îtLactalbumin content from whey. US Patent No. 5,008,376.

20. Lucas D, Rabiller-Baudry M, Millesime L, Chaufer B, Daufin G (1998) Extraction of a-lactalbumin from whey protein concentrate with modified inorganic membranes. J Membrane Sci 148: 1-12.

21. Muller A, Chaufer B, Merin U, Daufin G (2003) Purification of $\alpha$-lactalbumin from a prepurified acid whey: Ultrafiltration or precipitation. Lait 83: 439-451.

22. Mehra R, Kelley PM (2004) Whey protein fractionation using cascade membrane filtration. Bull No. 389. Int. Dairy Federation, Brussels, Belgium.

23. Marella C, Muthukumarappan K, Metzger LE (2011) Evaluation of commercially available, wide-pore ultrafiltration membranes for production of Ît-lactalbuminenriched whey protein concentrate. J Dairy Sci 94: 1165-1175.

24. Marella C, Salunke P, Metzger LE, Muthukumarappan K (2010) Production of $\alpha$ - Lactalbumin enriched concentrate from serum whey. Journal of Dairy Science 93: E-Suppl. 1

25. Anand S, Som Nath K, Marella C (2013) Whey and Whey Products. In: Milk and Dairy Products in Human Nutrition: Production, Composition and Health, Park YW, and Haenlein GFW (Eds). Composition and Health, John Wiley and Sons Ltd. Blackwell Publishing.

26. Vyas HK, Tong PS (2003) Process for calcium retention during skim milk ultrafiltration. J Dairy Sci 86: 2761-2766.

27. Mealy L, Marella C, Biswas A, Metzger LE (2013) Milk mineral harvest from dairy streams using filtration technology. Journal of Dairy Science 96: E-Suppl. 1

28. Peri C, Pompei C, Rossi F (1973) Process Optimization in Skim Milk Protein Recovery and Purification by Ultrafiltration. J Food Sci 38: 135-140.

29. Thompson SJ, deMan JM (1975) Concentration and Fractionation of Milk by Ultrafiltration. Can I Food Sc Tech J 8: 113-116.

30. Sikand V, Tong PS, Roy S, Rodriguez-Saona LE, Murray BA (2011) Solubility of commercial milk protein concentrates and milk protein isolates. J Dairy Sci 94: 6194-6202.

31. Havea $P$ (2006) Protein interactions in milk protein concentrate powders. Int Dairy J 16: 415-422.

32. Marella C, Salunke P, Biswas AC, Metzger LE (2013) Production of Milk Protein Concentrate with a Modified Mineral Content. Journal of Dairy Science 96 E-Suppl. 1.

33. Bhaskar GV, Singh H, Blazey ND (2007) Milk protein products and processes U.S patnent No. $7,157,108$

34. Mao XY, Tong PS, Gualco S, Vink S (2012) Effect of $\mathrm{NaCl}$ addition during diafiltration on the solubility, hydrophobicity, and disulfide bonds of $80 \%$ milk protein concentrate powder. J Dairy Sci 95: 3481-3488.

35. Marella C, Salunke P, Biswas AC, Metzger LE (2013) Impact of Calcium Reduction on the Functional Properties of Milk Protein Concentrate 80. Journal of Dairy Science 96: E-Suppl. 1. 